Molecular characterization of the gas/particle interface of soot sampled from a diesel engine using a titration method

\author{
A. Tapia ${ }^{1}$, M. S. Salgado ${ }^{*}$, María Pilar Martín', M. Lapuerta ${ }^{2}$, J. \\ Rodríguez-Fernández ${ }^{2}$, M. J. Rossi ${ }^{3}$ and B. Cabañas ${ }^{1}$ \\ ${ }^{1}$ Universidad de Castilla La Mancha. Departamento de Química Física, Facultad de \\ Ciencias y Tecnologías Químicas. Avda Camilo José Cela s/n, 13071 Ciudad Real, \\ Spain \\ ${ }^{2}$ Universidad de Castilla la Mancha. Grupo de Combustibles y Motores. Escuela \\ Técnica Superior de Ingenieros Industriales. Avda Camilo José Cela 10,13071 Ciudad \\ Real, Spain. \\ ${ }^{3}$ Labor für Atmosphärenchemie (LAC), Paul Scherrer Institute (PSI), OBBA006, CH- \\ 5232, Villigen PSI, Switzerland \\ *Corresponding author. Tel: (+34) 925295300-3450 \\ E-mail: sagrario.salgado@uclm.es (Sagrario Salgado) \\ NUMBER OF PAGES (INCLUDING THIS):10 \\ NUMBER OF FIGURES: 13 \\ NUMBER OF TABLES: 3
}




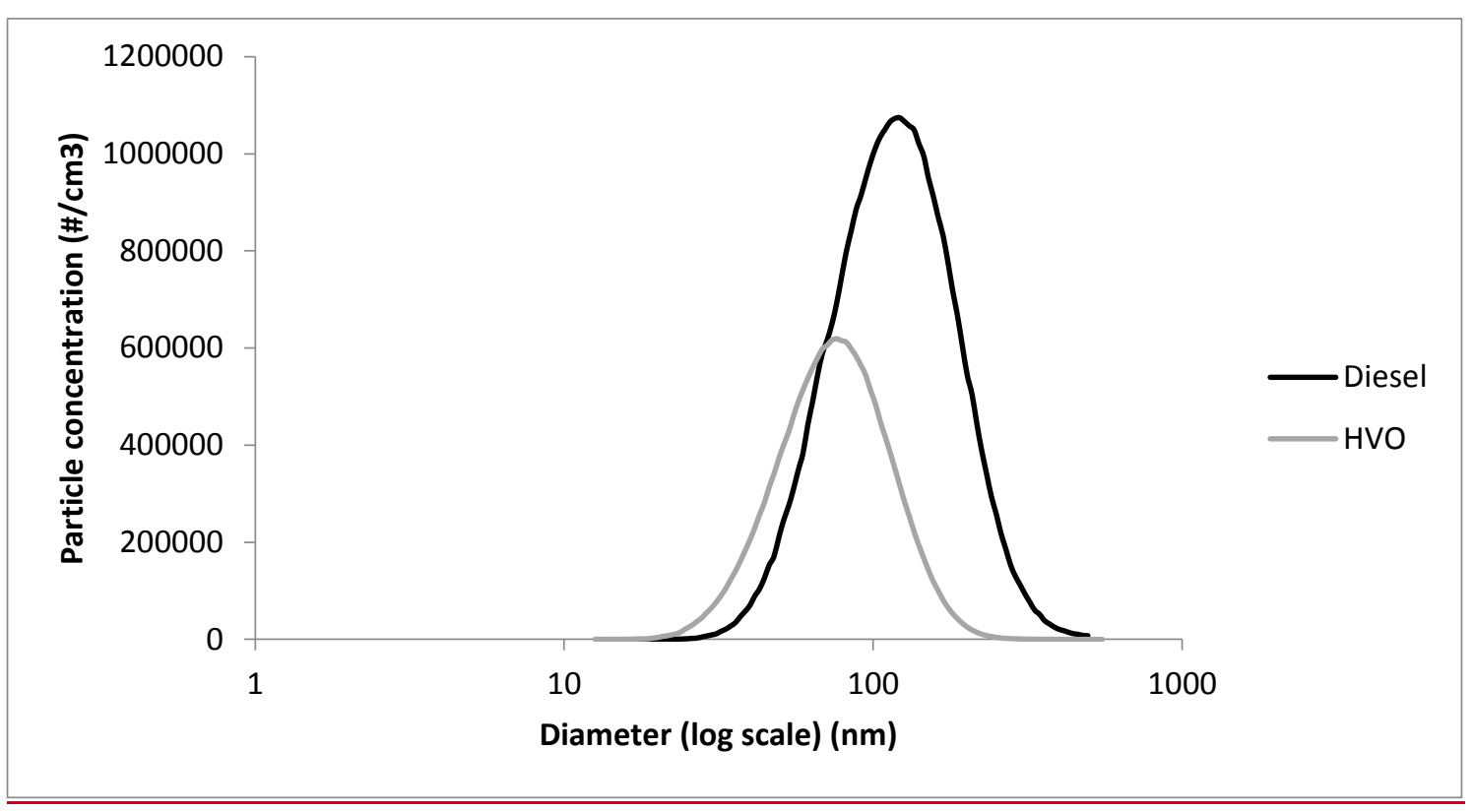

Figure 1S. Particle size distribution of the recovered diesel and HVO soot samples measured using a Scanning Mobility Particle Sizer (SMPS) device with Differential Mobility Analyser (DMA).

Table 1S. Parameters defining running conditions in the engine mode (U9) selected for the experiments.

\begin{tabular}{ccc}
\hline Measured variables & Units & $\begin{array}{c}\text { U9 } \\
\text { Mode }\end{array}$ \\
\hline Engine speed & $\mathrm{rpm}$ & 1667 \\
Effective torque & $\mathrm{Nm}$ & 78 \\
EGR Ratio & $\%$ & $22-23$ \\
Air flow & $\mathrm{kg} / \mathrm{h}$ & $\approx 78$ \\
Start of main injection & ${ }^{\circ} \mathrm{CA}(\mathrm{aTDC})$ & 5 \\
Start of pilot injection & ${ }^{\circ} \mathrm{CA}(\mathrm{bTDC})$ & 12.7 \\
Fuel injected during pilot injection & $\mu \mathrm{L} / \mathrm{inj}$ & 1.86 \\
Injection pressure & bar & 660 \\
\hline
\end{tabular}


Table 2S. Physico-chemical properties of pure fuels.

\begin{tabular}{|c|c|c|}
\hline Properties & Diesel & $\mathrm{HVO}$ \\
\hline Density at $15^{\circ} \mathrm{C} / \mathrm{kg} \mathrm{m}^{-3}$ & 811 & 779.6 \\
\hline Viscosity at $40^{\circ} \mathrm{C} / \mathrm{cSt}$ & 2 & 2.99 \\
\hline Lower heating value/ $\mathrm{MJ} \mathrm{kg}^{-1}$ & 43.13 & 43.955 \\
\hline Lubricity (WS1.4) / $\mu \mathrm{m}$ & 253 & 339.6 \\
\hline Cold filter plugging point $/{ }^{\circ} \mathrm{C}$ & -30 & -21 \\
\hline Acid number $/ \mathrm{mg}_{\mathrm{KOH}} \mathrm{g}^{-1}$ & 0.16 & 0.056 \\
\hline Water content / mg kg-1 & 60 & 19.2 \\
\hline Cetane number & 58.10 & 94.8 \\
\hline$\% \mathrm{C} / \mathrm{wt}$. & 85.74 & 84.68 \\
\hline$\% \mathrm{H} / \mathrm{wt}$ & 14.26 & 14.525 \\
\hline$\% \mathrm{O} / \mathrm{wt}$ & 0 & 0 \\
\hline Molecular formula & $\mathrm{C}_{13.39} \mathrm{H}_{26.72}$ & $\mathrm{C}_{13.95} \mathrm{H}_{28.7}$ \\
\hline Molecular weight & 187,4 & 196.1 \\
\hline Sulfur content / $\mathrm{mg} \mathrm{kg}^{1}$ & $<10$ & $<10$ \\
\hline
\end{tabular}

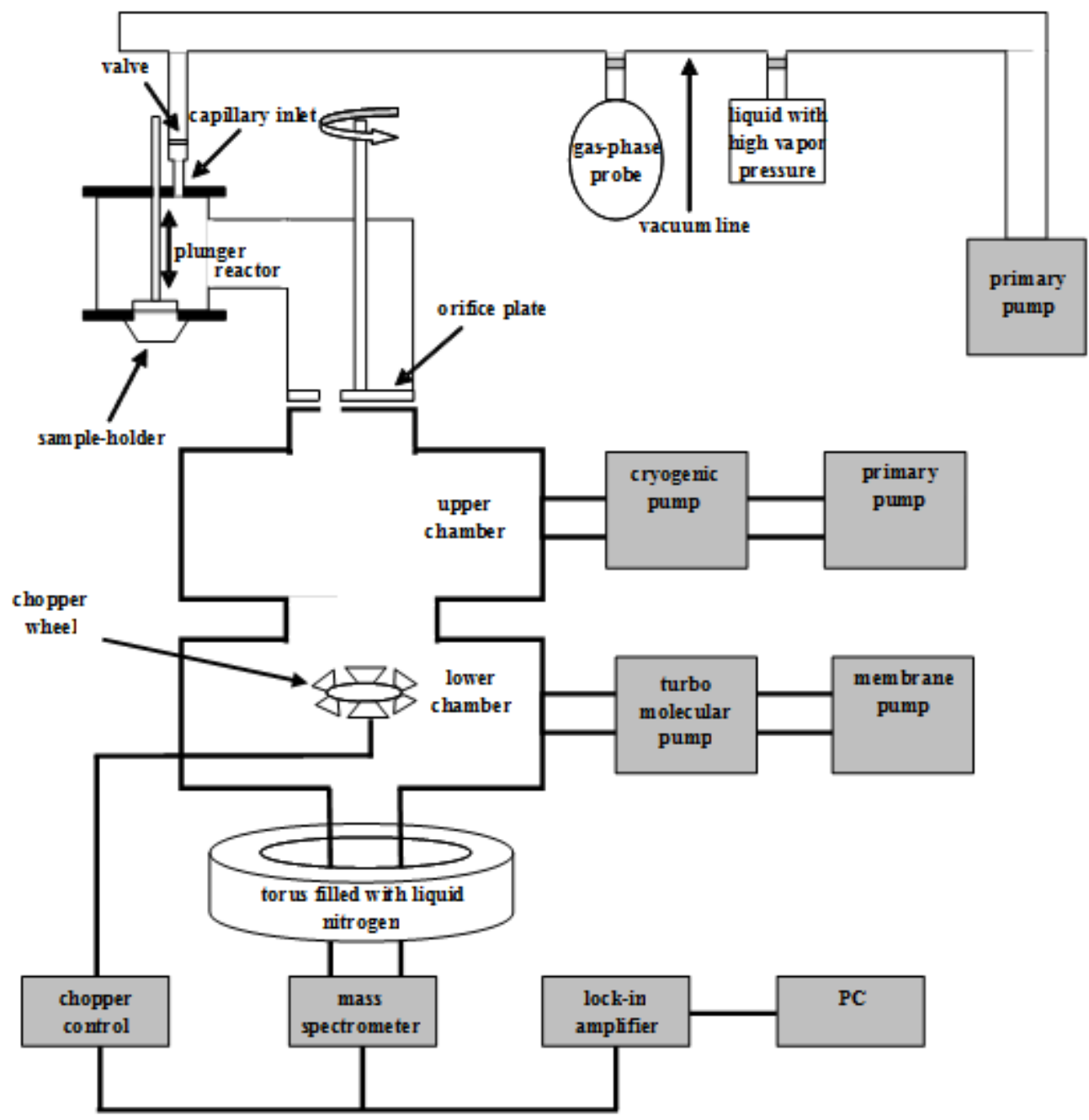

Figure 2S. Schematic drawing of the Knudsen flow reactor. 
Table 3S. Knudsen flow reactor parameters for the $1 \mathrm{~mm}$ nominal diameter aperture.

\begin{tabular}{ll}
\hline Parameter & Value \\
\hline Volume of the reactor & $\mathrm{V}=1830 \mathrm{~cm}^{3}$ \\
Estimated surface area of the reactor & $\mathrm{S}=1300 \mathrm{~cm}^{2}$ \\
Geometric surface area of the samples & $\mathrm{A}_{\mathrm{s}}=10.75 \mathrm{~cm}^{2}$ \\
Escape orifice diameter & $\varnothing=1 \mathrm{~mm}$ \\
Chopper frequency & $225 \mathrm{~Hz}$ \\
Escape rate constant ${ }^{a}$ & $\mathrm{k}_{\mathrm{esc}}=0.0058 \sqrt{T / M} \mathrm{~s}^{-1}$ \\
& \\
${ }^{a} \mathrm{~T}=$ temperature $/ \mathrm{K}, \mathrm{M}=$ molecular mass $/ \mathrm{g} \mathrm{mol}^{-1}$ & \\
\hline
\end{tabular}

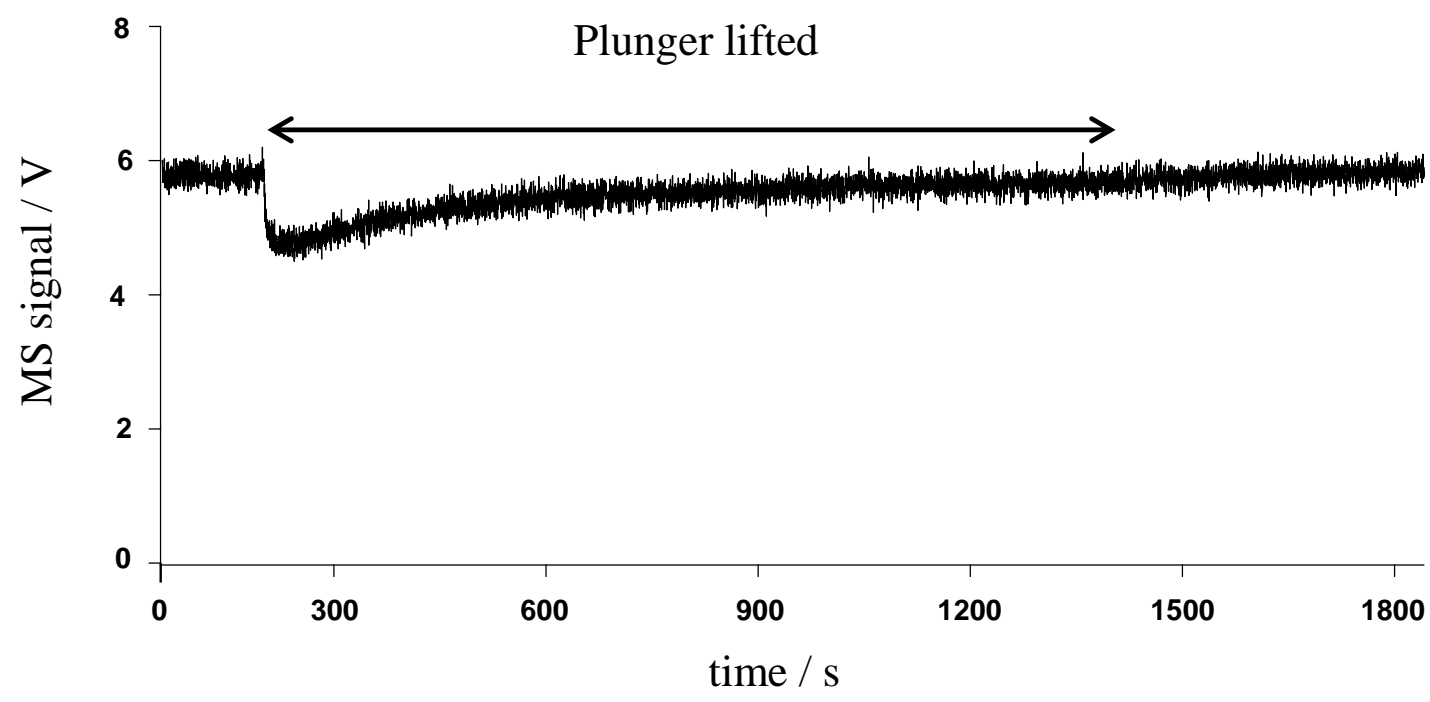

Figure 3S. Raw data of $\mathrm{NH}_{2} \mathrm{OH}$ uptake on empty cup at a flow rate of $2.95 \times 10^{15}$ molecule s-1 monitored at $\mathrm{m} / \mathrm{z} 33$ in the $1 \mathrm{~mm}$ diameter aperture Knudsen flow reactor $\left(\mathrm{k}_{\mathrm{esc}}=0.0173 \mathrm{~s}^{-1}\right)$. 


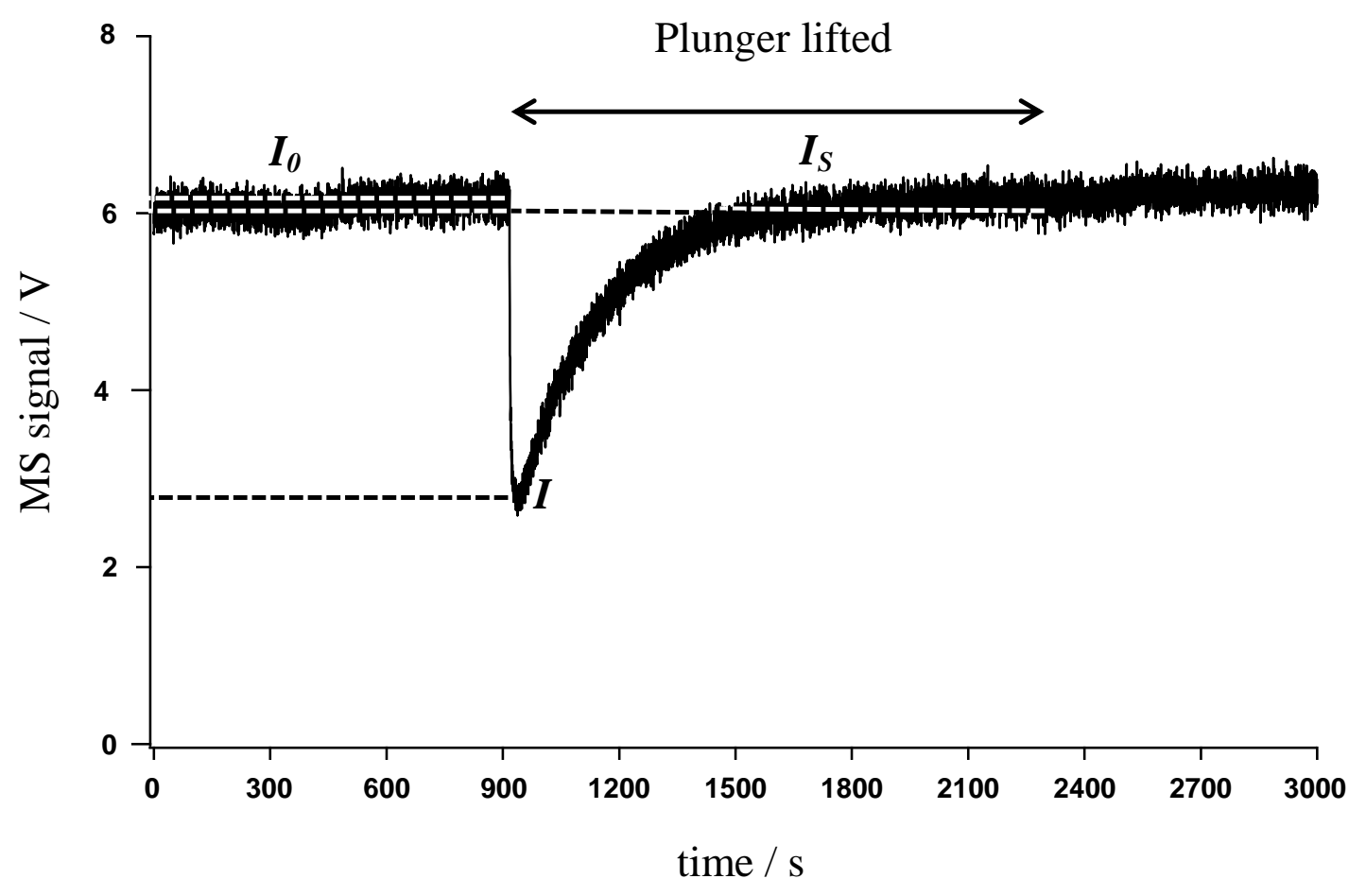

Figure 4S. Raw data of $\mathrm{N}\left(\mathrm{CH}_{3}\right)_{3}$ uptake on $16.02 \mathrm{mg}$ PRINTEX XE2-B soot at a flow rate of $3.41 \times 10^{15}$ molecule $\mathrm{s}^{-1}$ monitored at $\mathrm{m} / \mathrm{z} 58$ in the $1 \mathrm{~mm}$ diameter aperture Knudsen flow reactor $\left(\mathrm{k}_{\text {esc }}=0.013 \mathrm{~s}^{-1}\right.$ ) leading to the initial uptake coefficient $\gamma_{0}=3.37 \times 10^{-4}$. 


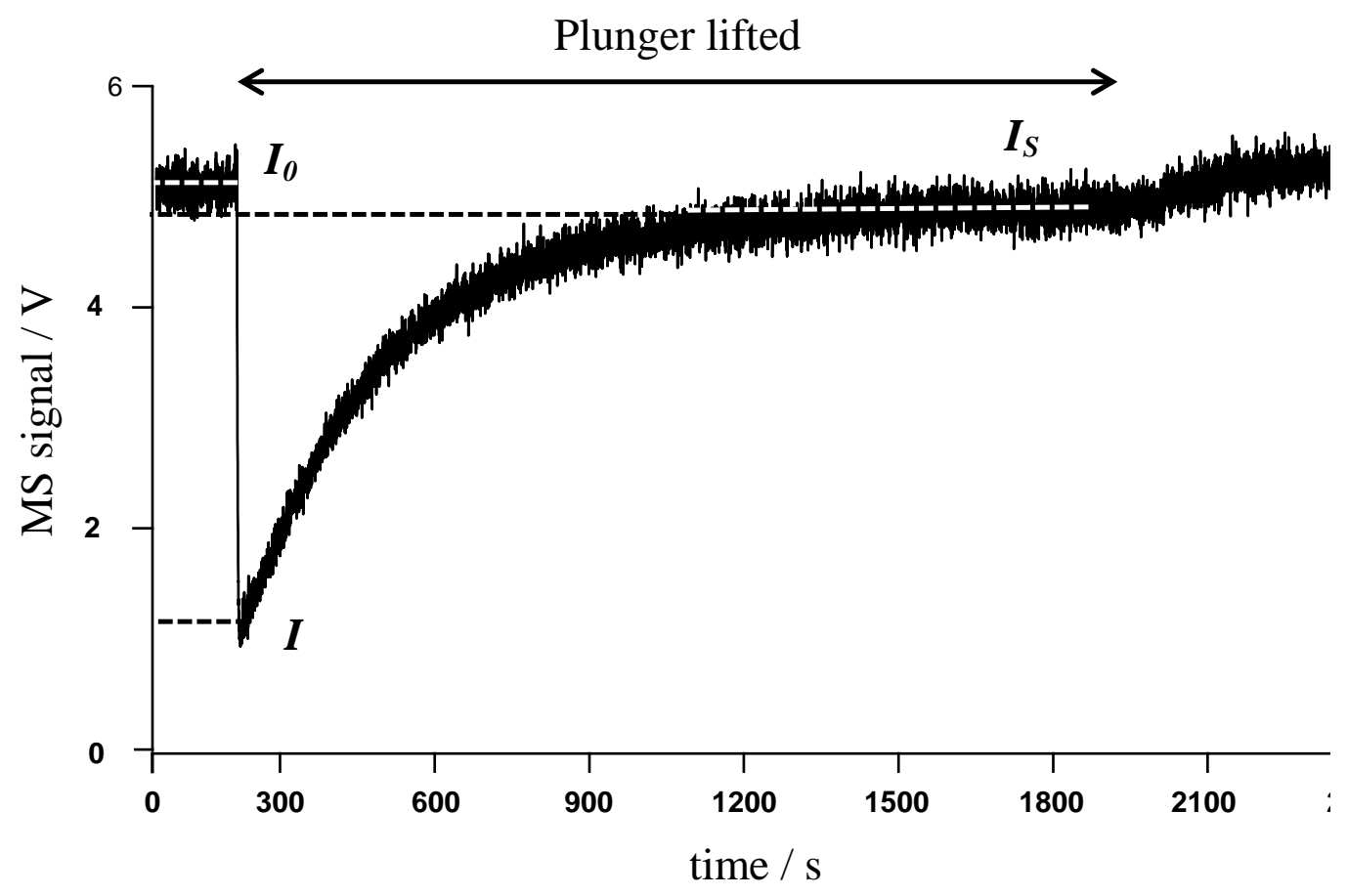

Figure 5S. Raw data of $\mathrm{NH}_{2} \mathrm{OH}$ uptake on $20.71 \mathrm{mg}$ Diesel soot at a flow rate of $6.07 \times 10^{15}$ molecule s${ }^{-1}$ monitored at $\mathrm{m} / \mathrm{z} 33$ in the $1 \mathrm{~mm}$ diameter aperture Knudsen flow reactor $\left(\mathrm{k}_{\mathrm{esc}}=0.0173 \mathrm{~s}^{-1}\right)$ leading to the initial uptake coefficient $\gamma_{0}=1.02 \times 10^{-3}$.

\section{Plunger lifted}

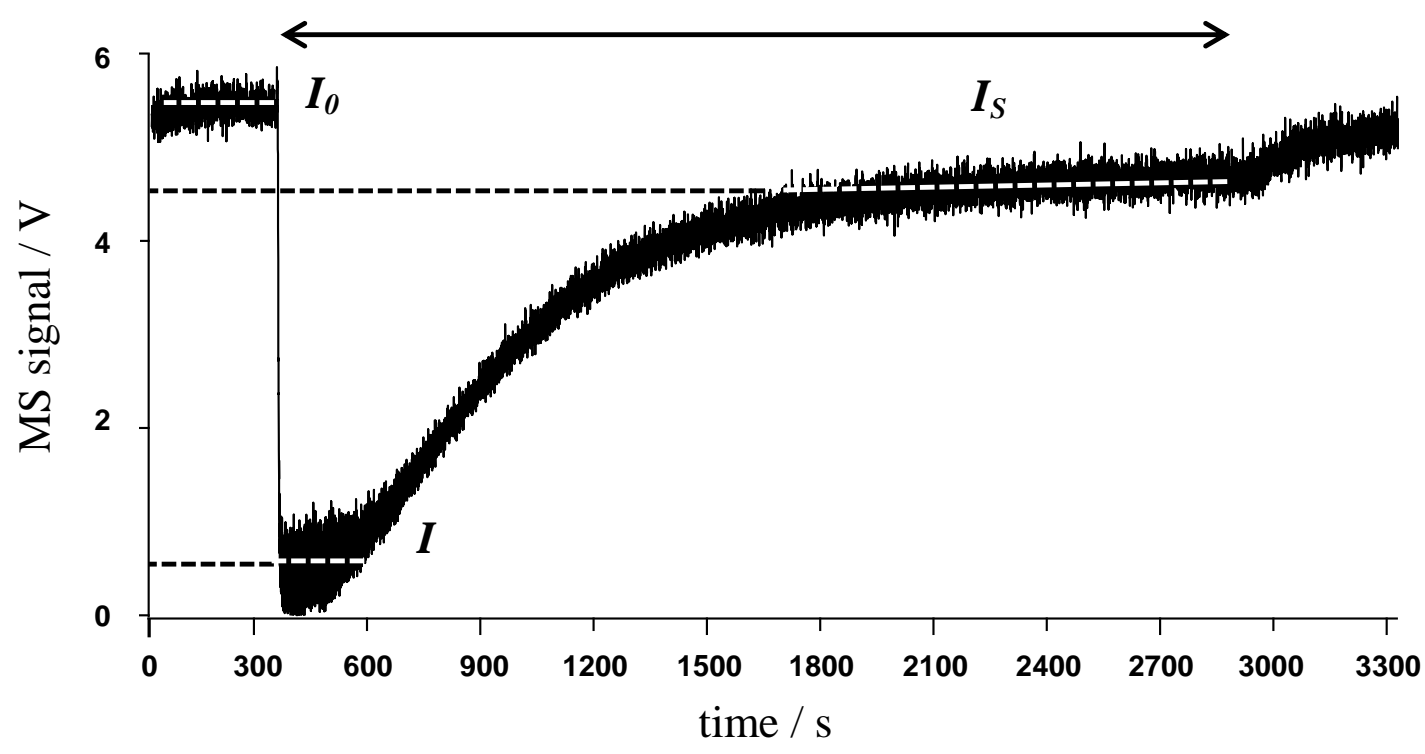

Figure 6S. Raw data of $\mathrm{NH}_{2} \mathrm{OH}$ uptake on $16.13 \mathrm{mg}$ HVO soot at a flow rate of $2.90 \times 10^{15}$ molecule s${ }^{-1}$ monitored at $\mathrm{m} / \mathrm{z} 33$ in the $1 \mathrm{~mm}$ diameter aperture Knudsen flow reactor $\left(\mathrm{k}_{\mathrm{esc}}=0.0173 \mathrm{~s}^{-1}\right)$ leading to the initial uptake coefficient $\gamma_{0}=4.40 \times 10^{-3}$. 


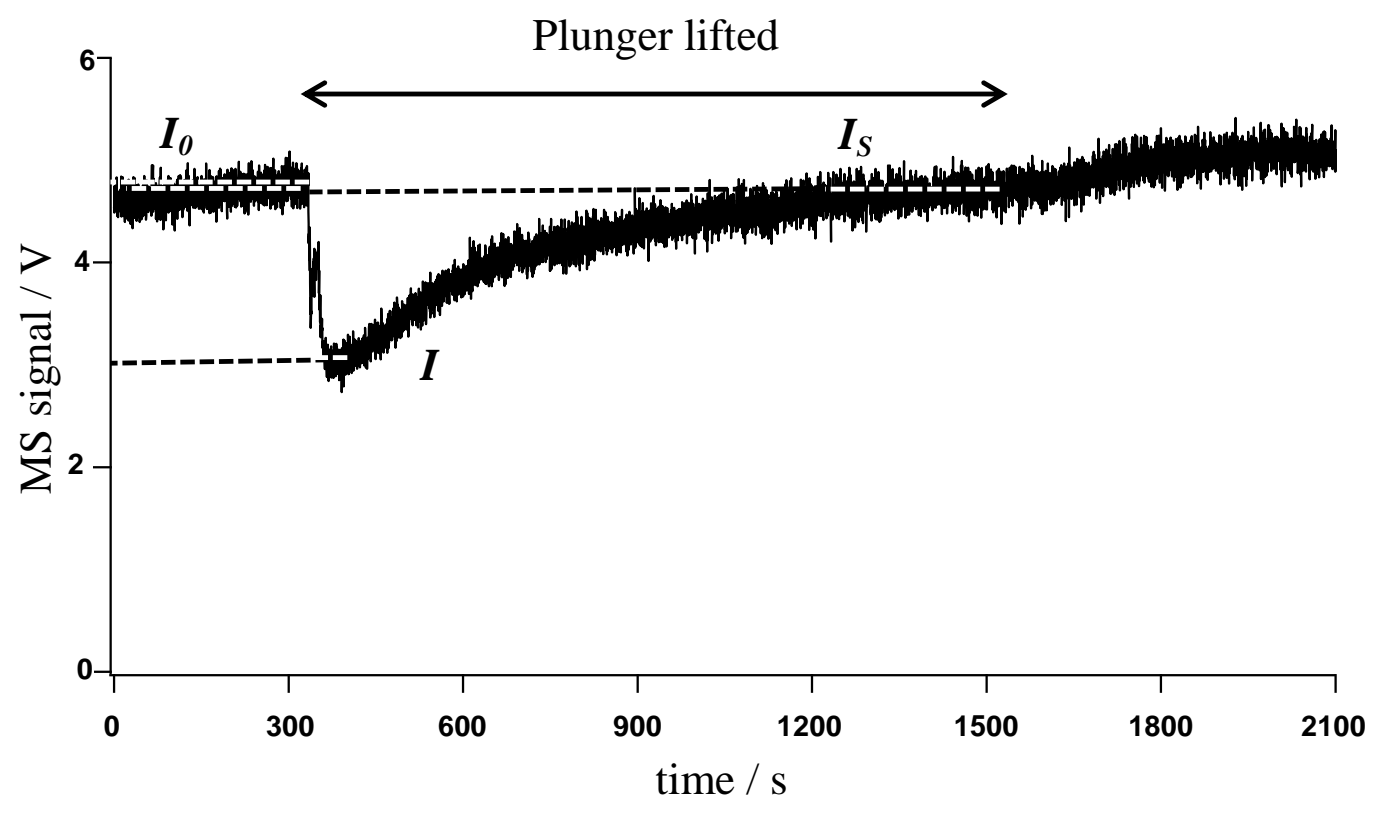

Figure 7S. Raw data of $\mathrm{NH}_{2} \mathrm{OH}$ uptake on $10.38 \mathrm{mg}$ PRINTEX XE-B soot at a flow rate of $6.15 \times 10^{15}$ molecule $\mathrm{s}^{-1}$ monitored at $\mathrm{m} / \mathrm{z} 33$ in the $1 \mathrm{~mm}$ diameter aperture Knudsen flow reactor $\left(\mathrm{k}_{\mathrm{esc}}=0.0173 \mathrm{~s}^{-1}\right)$ leading to the initial uptake coefficient $\gamma_{0}=1.58 \times 10^{-4}$.

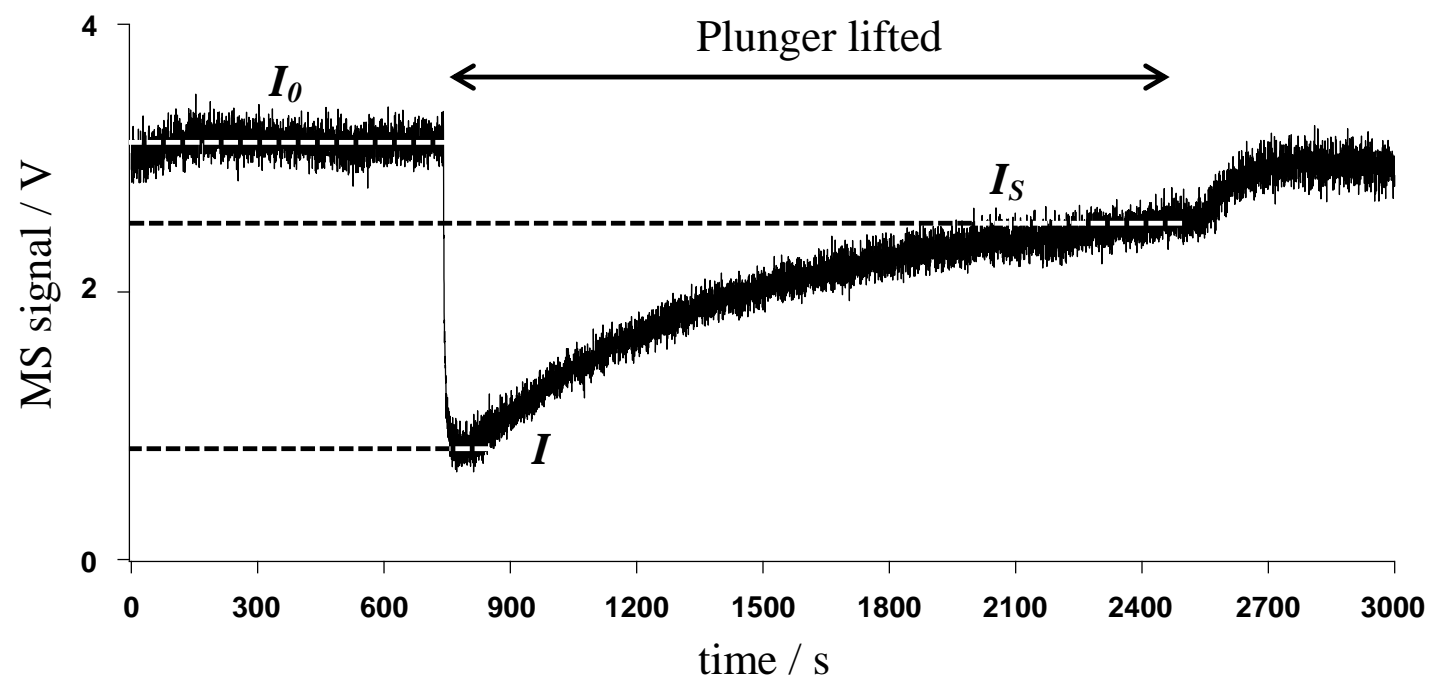

Figure 8S. Raw data of $\mathrm{CF}_{3} \mathrm{COOH}$ uptake on $15.15 \mathrm{mg}$ PRINTEX XE-B soot at a flow rate of $2.93 \times$ $10^{15}$ molecule s${ }^{-1}$ monitored at $\mathrm{m} / \mathrm{z} 69$ in the $1 \mathrm{~mm}$ diameter aperture Knudsen flow reactor $\left(\mathrm{k}_{\mathrm{esc}}=0.0093\right.$ $\mathrm{s}^{-1}$ ) leading to the initial uptake coefficient $\gamma_{0}=7.86 \times 10^{-4}$. 


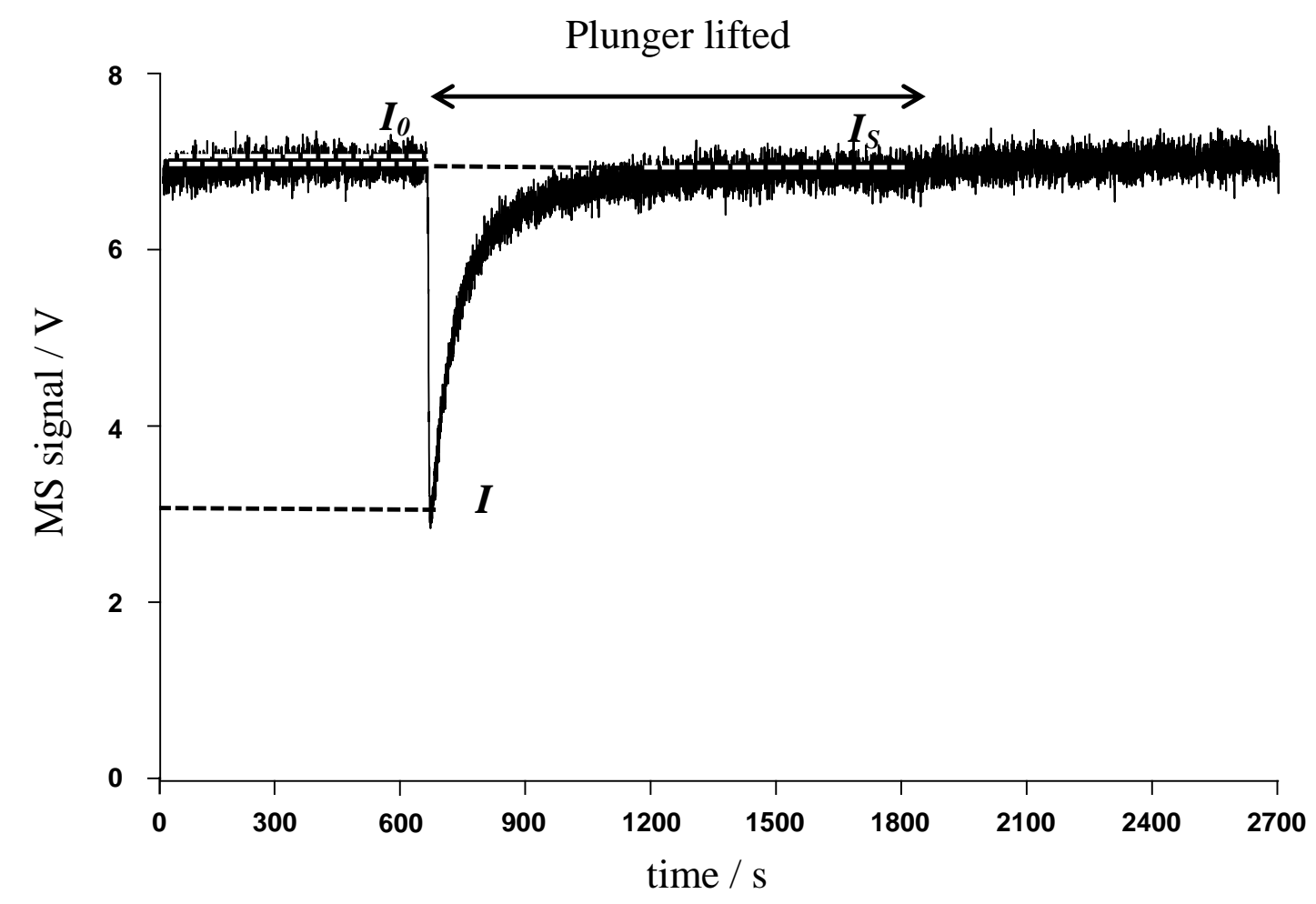

Figure 9S. Raw data of $\mathrm{HCl}$ uptake on $10.5 \mathrm{mg}$ Diesel soot at a flow rate of $4.66 \times 10^{15}$ molecule s$^{-1}$ monitored at $\mathrm{m} / \mathrm{z} 36$ in the $1 \mathrm{~mm}$ diameter aperture Knudsen flow reactor $\left(\mathrm{k}_{\mathrm{esc}}=0.0165 \mathrm{~s}^{-1}\right)$ leading to the initial uptake coefficient $\gamma_{0}=3.52 \times 10^{-4}$. 


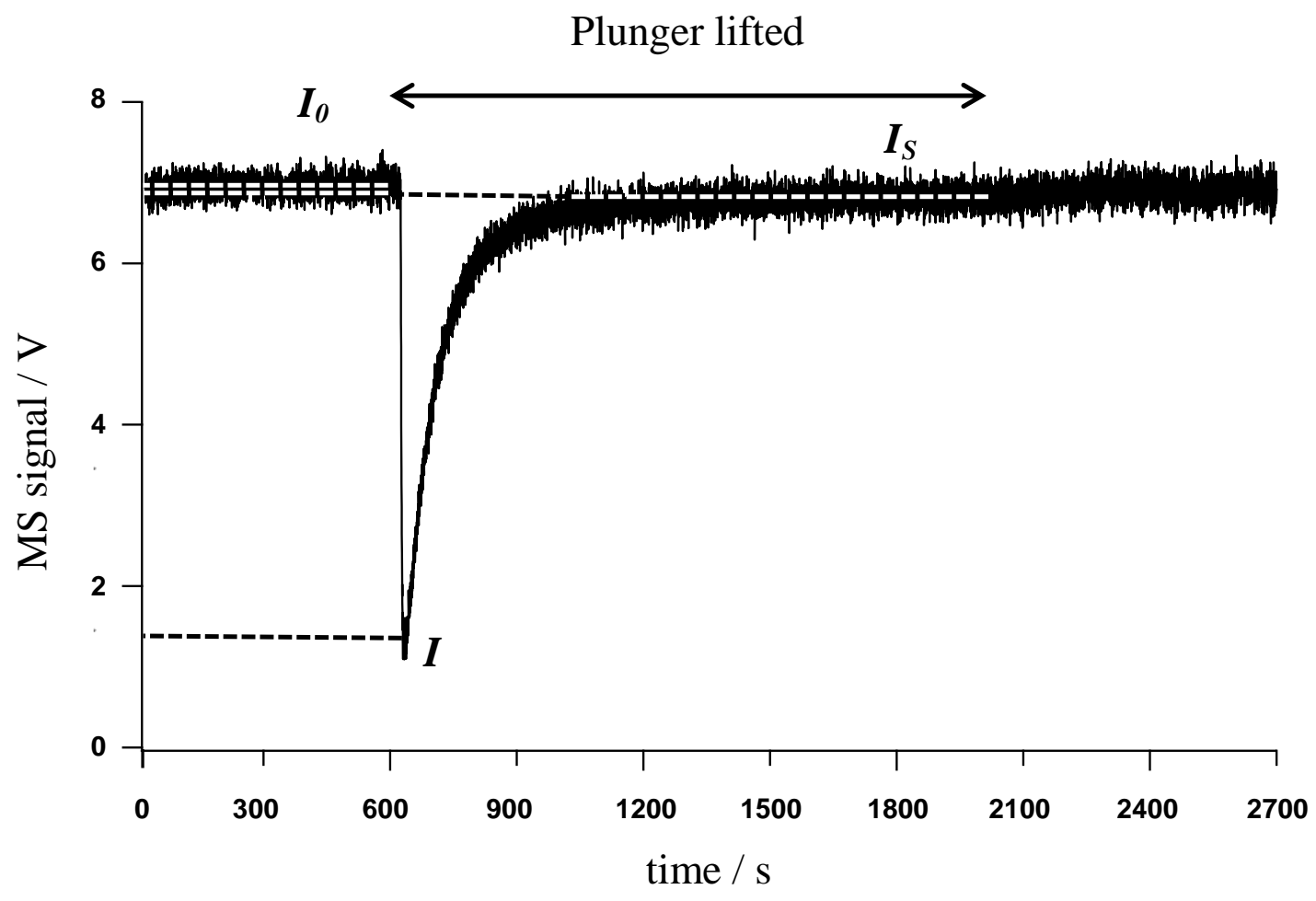

Figure 10S. Raw data of $\mathrm{HCl}$ uptake on $10.6 \mathrm{mg} \mathrm{HVO}$ soot at a flow rate of $4.48 \times 10^{15}$ molecule s$^{-1}$ monitored at $\mathrm{m} / \mathrm{z} 36$ in the $1 \mathrm{~mm}$ diameter aperture Knudsen flow reactor $\left(\mathrm{k}_{\mathrm{esc}}=0.0165 \mathrm{~s}^{-1}\right)$ leading to the initial uptake coefficient $\gamma_{0}=1.25 \times 10^{-3}$.

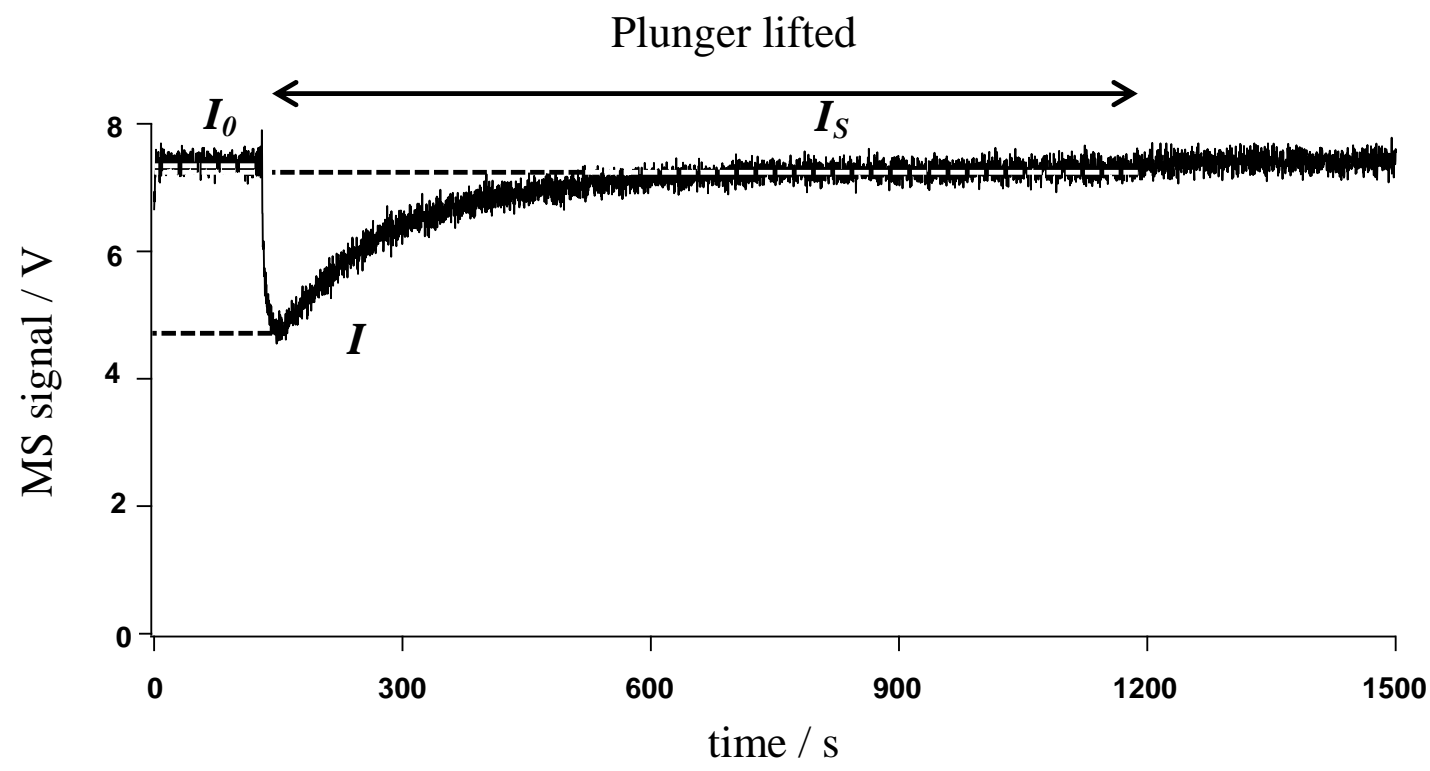

Figure 11S. Raw data of $\mathrm{HCl}$ uptake on $15.55 \mathrm{mg}$ PRINTEX XE-B soot at a flow rate of $5.32 \times 10^{15}$ molecule s${ }^{-1}$ monitored at $\mathrm{m} / \mathrm{z} 36$ in the $1 \mathrm{~mm}$ diameter aperture Knudsen flow reactor $\left(\mathrm{k}_{\mathrm{esc}}=0.0165 \mathrm{~s}^{-1}\right)$ leading to the initial uptake coefficient $\gamma_{0}=1.48 \times 10^{-4}$. 


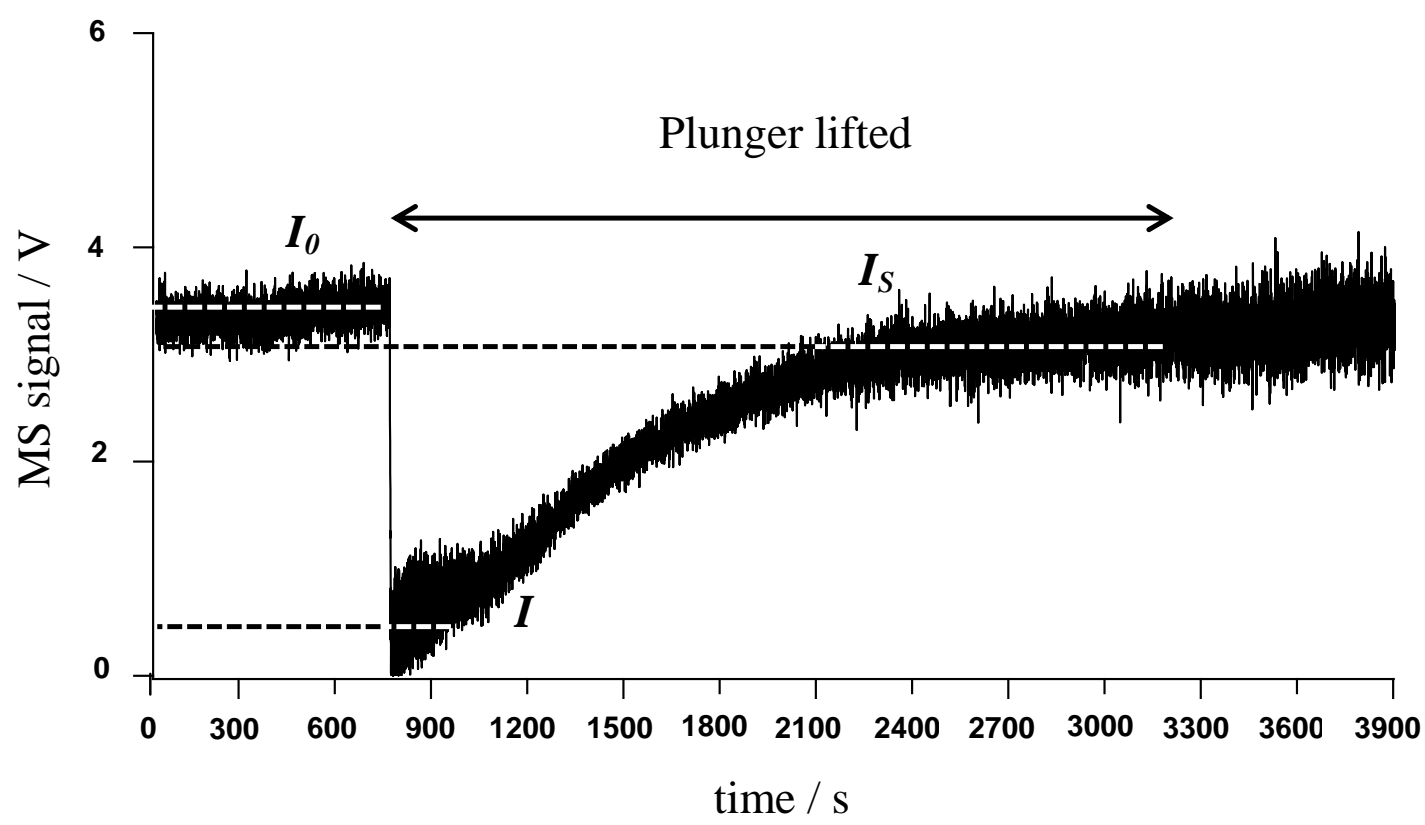

Figure 12S. Raw data of $\mathrm{NO}_{2}$ uptake on $16.4 \mathrm{mg}$ Diesel soot at a flow rate of $1.13 \times 10^{16}$ molecule s $\mathrm{s}^{-1}$ monitored at $\mathrm{m} / \mathrm{z} 46$ in the $1 \mathrm{~mm}$ diameter aperture Knudsen flow reactor $\left(\mathrm{k}_{\mathrm{esc}}=0.0167 \mathrm{~s}^{-1}\right)$ leading to the initial uptake coefficient $\gamma_{0}=3.56 \times 10^{-3}$.

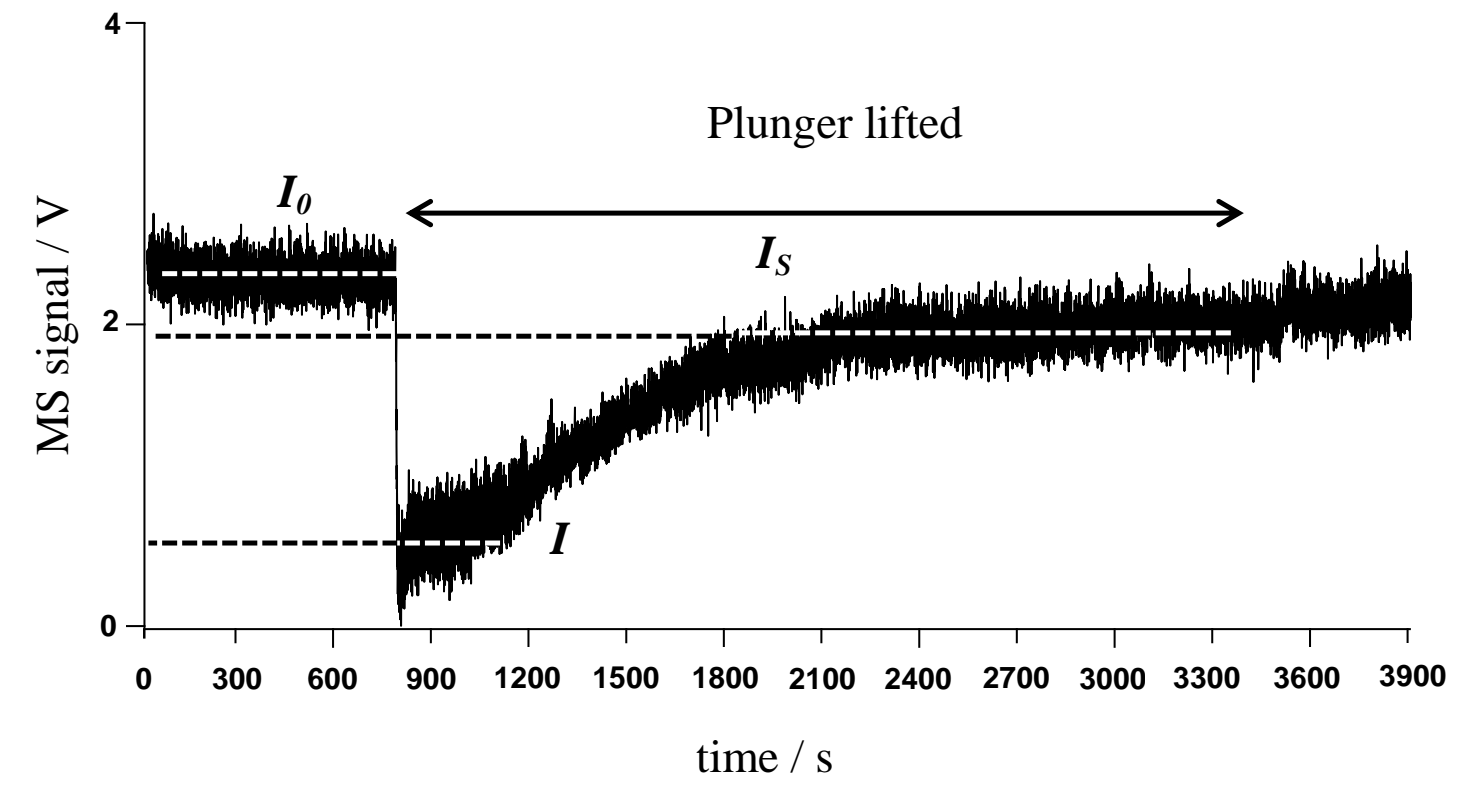

Figure 13S. Raw data of $\mathrm{NO}_{2}$ uptake on $11.85 \mathrm{mg} \mathrm{HVO}$ soot at a flow rate of $8.36 \times 10^{15}$ molecule s${ }^{-1}$ monitored at $\mathrm{m} / \mathrm{z} 46$ in the $1 \mathrm{~mm}$ diameter aperture Knudsen flow reactor $\left(\mathrm{k}_{\mathrm{esc}}=0.010 \mathrm{~s}^{-1}\right)$ leading to the initial uptake coefficient $\gamma_{0}=6.16 \times 10^{-4}$. 